\title{
First nesting record of the Bay-Capped Wren-Spinetail Spartonoica maluroides (Aves, Furnariidae) in Brazil, with nest and nestling descriptions and notes on breeding behavior
}

\author{
Rafael A. Dias ${ }^{1}$, Maycon S. S. Gonçalves ${ }^{2} \&$ Vinicius A. G. Bastazini ${ }^{1}$
}

1. Programa de Pós-graduação em Ecologia, Instituto de Biociências, Universidade Federal do Rio Grande do Sul, Av. Bento Gonçalves 9500, setor 4, prédio 43422, Caixa Postal 15007, 91540-000 Porto Alegre, RS, Brazil. (rafael_antunes_dias@yahoo.com.br)

2. Laboratório de Ecologia e Conservação de Ecossistemas Aquáticos, Universidade do Vale do Rio dos Sinos, Avenida UNISINOS, 950, 93022-000 São Leopoldo, RS, Brazil.

\begin{abstract}
The only breeding record of Spartonoica maluroides (d'Orbigny \& Lafresnaye, 1837) for Brazil is based on the observation of a fledgling in southern Rio Grande do Sul in January 1976. On 7 December 2005 we discovered a nest containing three nestlings at the southeastern end of Lagoa Pequena, municipality of Pelotas, Rio Grande do Sul. The nest was concealed at the base of a cavity in a Spartina densiflora (Poaceae) tussock located at the edge of a saltmarsh. The nest was built of fine pieces of dead Scirpus olneyi (Cyperaceae) and S. densiflora leaves firmly interlaced to the internal leaves of the tussock. Live leaves of S. densiflora lining the cavity comprised a substantial part of the nest's architecture, forming most of its upper lateral walls and roof. The lower section was more elaborate, resembling a deep cup and forming a distinct incubation chamber. Adults reached the nest's interior through an irregular apical opening amidst the leaves. The nest was $244 \mathrm{~mm}$ high and $140 \mathrm{~mm}$ wide. The incubation chamber had an external diameter of $138.5 \mathrm{~mm}$, an internal diameter of $79.4 \mathrm{~mm}$ and was $86 \mathrm{~mm}$ deep. It was lined with fine leaves and white plant fibers. Nestlings were five to six days old. A total of 107 neossoptiles restricted to the capital, spinal and alar tracts were recorded in one nestling. The distribution of neossoptiles in the ocular region of $S$. maluroides forms a distinct pattern which can be typical of Furnariidae and related families. Two adults attended the nest, bringing small insects to the nestlings and removing fecal sacs. We recorded at least 74 visits to the nest during a $c a .6 \mathrm{~h}$ period during an afternoon. The average number of visits per hour was $12.8 \pm 1.3$. An adult bird spent on average $0.7 \pm 0.56$ minutes inside the nest attending nestlings. The nest remained unattended on average for $3.61 \pm 3.13$ minutes. The hour of the day had no influence on the amount of time spent by an adult in the nest or away from it. We returned to the area on 15 December 2005 and found the nest abandoned. Observations confirm that $S$. maluroides is a resident breeder in southern Brazil and that the saltmarshes of the Lagoa do Patos estuary are an important year-round habitat for the species. A nestling and the nest were collected to document the record.
\end{abstract}

KEYWORDS. Natal pterylosis, saltmarsh, conservation, Lagoa dos Patos, Rio Grande do Sul.

RESUMO. Primeiro registro de nidificação da boininha Spartonoica maluroides (Aves, Furnariidae) no Brasil, incluindo a descrição do ninho e ninhego e notas sobre o comportamento reprodutivo. O único registro de reprodução de Spartonoica maluroides (d'Orbigny \& Lafresnaye, 1837) no Brasil é baseado na observação de um filhote recém-saído do ninho no sul do Rio Grande do Sul em janeiro de 1976. Em 7 de dezembro de 2005, descobrimos um ninho contendo três filhotes na extremidade sudoeste da Lagoa Pequena, município de Pelotas, Rio Grande do Sul. O ninho estava oculto na base de uma cavidade dentro de uma touceira de Spartina densiflora (Poaceae) situada na margem de uma marisma. O ninho era constituído de pedaços delgados de folhas mortas de Scirpus olneyi (Cyperaceae) e $S$. densiflora firmemente entrelaçados às folhas da touceira. Folhas vivas de $S$. densiflora que orlavam a cavidade compreendiam uma parte substancial da arquitetura do ninho, constituindo a maior parte da porção superior das paredes laterais e o teto. A seção inferior era mais elaborada, similar a uma taça profunda e formando uma câmara incubatória distinta. Os adultos acessavam o ninho através de uma abertura apical de formato irregular por entre as folhas. O ninho media $244 \mathrm{~mm}$ de altura e $140 \mathrm{~mm}$ de largura. A câmara incubatória apresentava um diâmetro externo de $138,5 \mathrm{~mm}$, um diâmetro interno de $79,4 \mathrm{~mm}$ e uma profundidade de $86 \mathrm{~mm}$, sendo forrada de folhas delgadas e fibras vegetais brancas. Os ninhegos tinham de cinco a seis dias de idade. Um ninhego exibiu um total de 107 neossóptilas restritas aos tratos capital, espinal e alar. A distribuição das neossóptilas na região ocular de S. maluroides forma um padrão distinto que pode ser típico de Furnariidae e famílias afins. Dois adultos atendiam o ninho, trazendo pequenos insetos para os ninhegos e removendo sacos fecais. Registramos pelo menos 74 visitas ao ninho em um período de $c a$. $6 \mathrm{~h}$ durante uma tarde. $\mathrm{O}$ número médio de visitas por hora foi de $12,8 \pm 1,3$. Os adultos permaneceram em média $0,7 \pm 0,56$ minutos dentro do ninho atendendo os filhotes. O ninho permaneceu sem atendimento em média por 3,61 $\pm 3,13$ minutos. O horário do dia não influenciou o tempo de permanência dos adultos no ninho ou longe deste. Retornamos ao local em 15 de dezembro de 2005 e encontramos o ninho abandonado. Observações confirmam que S. maluroides é um residente reprodutor no sul do Brasil e que as marismas do estuário da Lagoa dos Patos constituem um importante hábitat para a espécie durante todo o ano. Um ninhego e o ninho foram coletados para documentar o registro.

PALAVRAS-CHAVE. Pterilose natal, marisma, conservação, Lagoa dos Patos, Rio Grande do Sul.

The Bay-Capped Wren-Spinetail Spartonoica maluroides (d'Orbigny \& Lafresnaye, 1837) is a small furnariid that lives mainly in fresh and brackish water wetlands covered with sedges, reeds, and other types of dense, tall, herbaceous vegetation, including mature ricefields (Ridgely \& Tudor, 1994; Remsen, 2003; Dias \& BURGER, 2005). It occurs in central Argentina, Uruguay and southern Brazil (Ridgely \& TUdOR, 1994; REMSEN, 2003). Brazilian records are restricted to the southern half of the state of Rio Grande do Sul, chiefly along the Coastal Plain (Belton, 1984, 1994; Sick, 1997; BencKE et al., 2003). Unless disturbed, this secretive bird remains hidden in dense vegetation (Wetmore, 1926; Pereyra, 1938; HudSON, 1984; RidgelY \& TUdOR, 1994). Therefore, very little is known of its biology and ecological requirements. Due to habitat destruction and modification - a consequence of overgrazing, burning and the drainage and conversion of wetlands to agriculture and urban 
development $-S$. maluroides is considered globally nearthreatened with extinction and formally threatened in the State of Rio Grande do Sul (BENCKE et al., 2003; BIRDLIFE INTERNATIONAL, 2007).

The nest of this species is unique among ovenbirds. Rather than constructing a covering dome, the bird relies on dense vegetation to shelter it from above, building the nest near the ground at the base of tussocks (NAROSKY, 1973; ZyskowsKi \& PRUM, 1999; REMSEN, 2003). Basic aspects of its breeding biology, such as the span of the breeding season, nest description, laying period and clutch size, are already known (DURNFORD, 1878; HARTERT \& Venturi, 1909; Grant, 1911; Wetmore, 1926; Pereyra, 1938; NAROSKY, 1973; HudSON, 1984; FraGA \& NAROSKY, 1985; Belton, 1994; BencKe et al., 2003). Data on parental behavior and nestling description is lacking. Apart from records of birds defending territories and sightings of juveniles, the strongest evidence of breeding in Brazil is based on the observation of a fledgling in southern Rio Grande do Sul on 7 January 1976 (BELTON, 1984; BENCKE et al., 2003).

In this paper we provide the first documented breeding record of the species for Brazil and supplement the scant knowledge on its breeding habits by describing a nest. We also provide the first description of a nestling and present quantitative data on previously unknown parental behavior.

\section{MATERIAL AND METHODS}

Study area. Observations were conducted at the southwestern end of Lagoa Pequena, a mid-sized lagoon in the municipality of Pelotas, State of Rio Grande do Sul, Brazil. The nest site ( $\left.31^{\circ} 41^{\prime} 01.9^{\prime \prime} \mathrm{S}, 52^{\circ} 06^{\prime} 13.3^{\prime \prime} \mathrm{W}\right)$ is located near the confluence of the Canal do Possedônio - a small inlet of the Lagoa Pequena - and the Lagoa dos Patos, the largest of Rio Grande do Sul's coastal lagoons. The study area marks the northern limit of the estuary of the Lagoa dos Patos (Asmus, 1998). Altitude is around sea-level. Climate in Pelotas municipality is classified as humid subtropical with uniform precipitation distribution (Cfa) according to Köppen's climate classification system (RosA, 1985). Yearly rainfall averages 1,249 $\mathrm{mm}$ and the mean annual temperature is $17.6^{\circ} \mathrm{C}$ (RosA, 1985). Saltmarshes dominated by Scirpus olneyi (Cyperaceae) cover most of the area. Sparse tussocks of Spartina densiflora (Poaceae) and small patches of Schoenoplectus californicus (Cyperaceae) are also found in the wetland, especially along its borders. The marsh remains flooded with a few centimeters of water for most of the year, only drying in summers with very low rainfall. Despite the presence of cattle grazing impact appears to be low.

Methods. We discovered a nest containing three nestlings at 11:30 on 7 December 2005 by following adult birds carrying food in their bills. Data obtained in the field were recorded from 11:30 to 18:00. We returned to the area on 15 December 2005 in order to make further observations, but the nest was abandoned. Nest measurements were taken at the nest site with a caliper (to the nearest $0.1 \mathrm{~mm}$ ) and a measuring tape (to the nearest $1.0 \mathrm{~mm}$ ). Since the nest was somewhat mingled to the supporting plant, measurements correspond to portions of the construction were leaves deliberately woven by the birds were found. To avoid disturbance, only one of the nestlings was removed from the nest and photographed. After observations on behavior were concluded, we collected a nestling for further studies and documentation. Nestling description is based on data taken from this specimen mostly in the laboratory. Nestling age was inferred from descriptions of other furnariid nestlings in Fraga (1980), Bosque \& Lentino (1987) and NoREs \& Nores (1994). Nomenclature of colors follows Smithe (1975). Methods for the description of natal pterylosis, nomenclature of pterylae and regions, and classification of nestlings in stages of age based on general feather development, follow Wetherbee (1957). Nomenclature and regions of teleoptile pterylography for pin feathers were based on CLENCH (1970). Nestling measurements were taken with a caliper to the nearest 0.1 $\mathrm{mm}$.

Parental care was recorded from 11:55 to 17:51 by two observers hidden $\mathrm{ca} .20 \mathrm{~m}$ away from the nest using 12 x 50 binoculars. Nesting behavior was recorded using the "focal animal" sampling method (AltMAN, 1974). Each time an adult arrived at the nest was considered a visit. We recorded the time the adults spent in the nest attending nestlings and away during foraging activities to the nearest second. The number and duration of the adults' foraging bouts could not be determined because individual birds were unrecognizable. Whenever possible, we determined the direction adult birds took after leaving the nest. We grouped the number of visits in one-hour intervals and used chi-square analysis to test if there were differences among them. We used simple linear regression to test if the time spent by the adults attending chicks in the nest and the interval the nest remained unattended (an indirect measure of the adults' feeding bouts) was influenced by the time of the day. To do so, we calculated the interval in minutes from each observation to the time of sunset (i.e., 19:18) and used this value as the independent variable. Data are reported as mean \pm SD. All statistical tests were performed at a minimum level of $P<0.05$ using BioEstat 5.0 (Ayres et al., 2007) statistical package.

The nest and a nestling were collected and deposited at the ornithological collection of the Museu de Ciências e Tecnologia/Pontifícia Universidade Católica do Rio Grande do Sul, Porto Alegre, Brazil.

\section{RESULTS}

Nest description. Nest site was at the border of the saltmarsh, some $25 \mathrm{~m}$ from the shore of the Lagoa dos Patos, where a very small and shallow tidal channel cuts through a narrow, low, beach line. The nest was concealed deep in a cavity in the interior of a $1.3 \mathrm{~m}$ high tussock of Spartina densiflora (Figs. 1, 2) located on the edge of the lower (0.7-0.9 m) $S$. olneyi stand. A small patch of $S$. californicus stood some $15 \mathrm{~m}$ away. A few smaller patches of Scirpus californicus (Cyperaceae) and additional tussocks of $S$. densiflora were also situated in the proximity. The nest was constructed in the central, densest portion of the tussock, some $400 \mathrm{~mm}$ from its 
laterals. No signs of it were visible from the outside. The distance from the apex of the nest to the tip of the tussock was $750 \mathrm{~mm}$. The base of the nest stood $280 \mathrm{~mm}$ from the ground. The soil near the nest was dry, but mud and some water were found in deeper sections of the marsh nearby, especially in the $S$. californicus patches and in small tidal channels.

The nest was built of fine pieces of dead $S$. olneyi and $S$. densiflora leaves measuring $252 \mathrm{~mm} \pm 40.87(n=5)$ long and $c a .1 \mathrm{~mm}$ thick, firmly interlaced to the internal leaves of the tussock (Fig. 3). Such pieces of dead leaves were abundant on the ground and at the base of live plants around the nest site. The internal leaves of $S$. densiflora lining the tussock's inner cavity comprised a substantial part of the nest's architecture, forming most of its upper lateral walls and roof. The lower section was more elaborate, resembling a deep cup and forming a distinct incubation chamber. The nest was $244 \mathrm{~mm}$ high and $140 \mathrm{~mm}$ wide. Adults reached the nest's interior through an irregular apical opening amidst the leaves approximately $45 \mathrm{~mm}$ wide. This opening could be reached either from the top of the tussock or through its laterals via spaces in the plant's leaves. The incubation chamber had an external diameter of $138.5 \mathrm{~mm}$, an internal diameter of $79.4 \mathrm{~mm}$ and was $86 \mathrm{~mm}$ deep. It was lined with fine leaves measuring $53.27 \mathrm{~mm} \pm 36.71(n=33)$ long and $c a .1$ mm thick. A few white plant fibers similar to cotton covered its floor.

Nestling description. Three nestlings five to six days old occupied the nest's inner cup. Begging was not audible from the nest's exterior. When handled, a nestling emitted a series of simple high-pitched squeaks. Movements were restricted to head rising and mouth opening. Eyes were partially open and the egg tooth was absent (Fig. 4).

Juvenal contour feathers had erupted through the skin but had not ruptured their sheaths. Based on general feather development, nestling corresponds to Stage C. Sparse Lavander (\# 77) neossoptiles were restricted to the capital, spinal and alar tracts (Tab. I; Fig. 5). A total of 107 neossoptiles was recorded. Pin feathers of the dorsal, scapulohumeral, caudal, alar and a narrow band on the internal portion of the main element of the ventral tracts varied between Smalt Blue (\# 170) and Indigo (\# 73). These colors were also predominant on the femoral tract, with the exception of a narrow Clay Color (\# 123C) to Yellow Ocher (\# 123C) band along its ventral limit. Pins of the remainder of the ventral and the entire crural tracts were also Clay Color (\# 123C) to Yellow Ocher (\# 123C). Pins of most of the capital tract were Smalt Blue (\# 170) and Indigo (\# 73), with the exception of the chin, throat and a small portion of the postauricular region, which were Clay Color
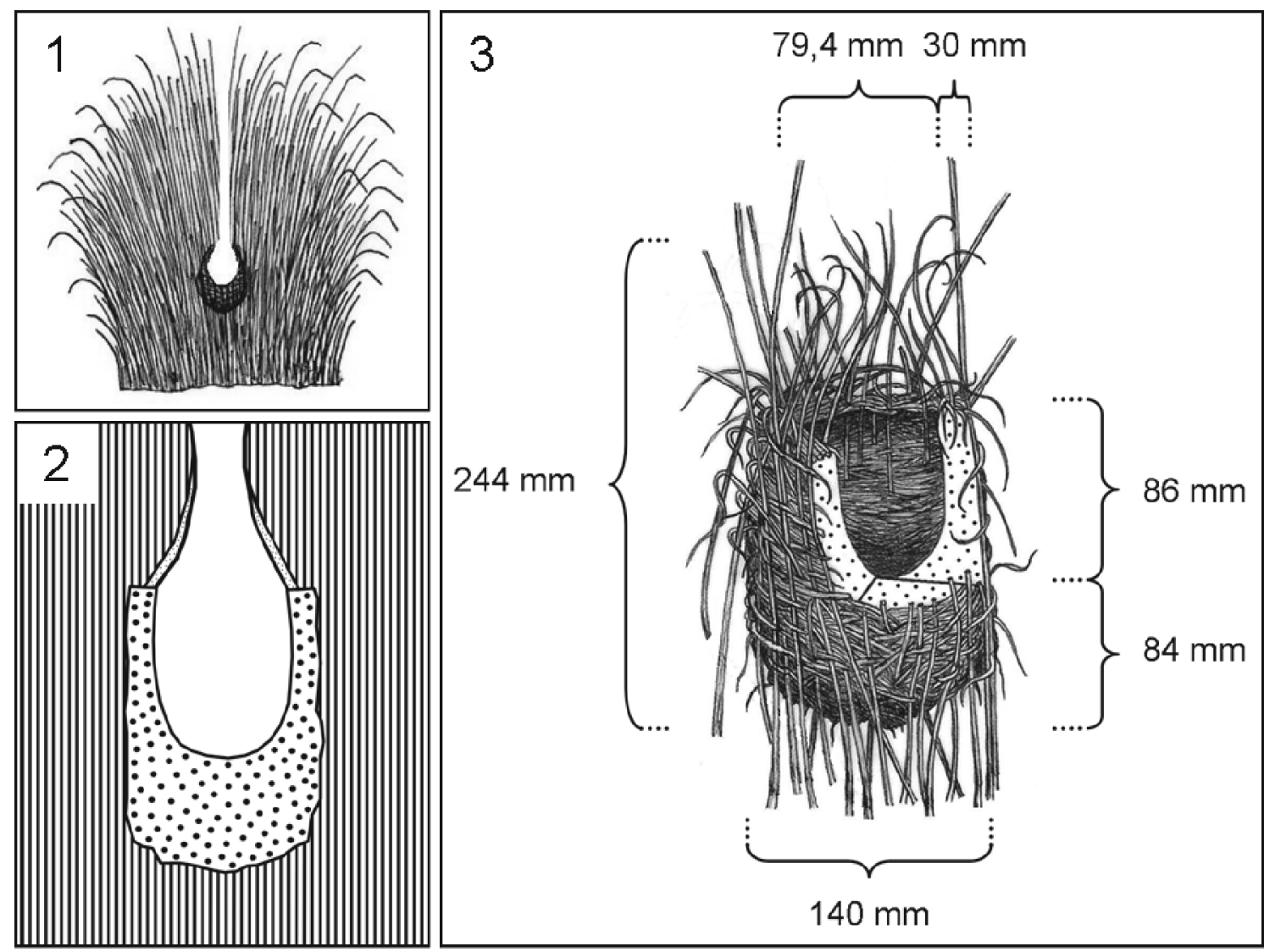

Figures. 1-3. A nest of Spartonoica maluroides (d'Orbigny \& Lafresnaye, 1837) from southern Brazil: 1, position of the nest in a Spartina densiflora (Poaceae) tussock; 2, schematic illustration of the nest (vertical lines represent the leaves of the tussock, while the dotted area depicts the cup built at the bottom of the cavity; the slightly curved figures above the incubation chamber represent leaves of the tussock that have been deliberately arranged by the birds to form a canopy); 3 , nest and measurements. A substantial number of live vertical leaves, all part of the supporting plant, were removed or cut to allow better visualization. A portion of the outer wall was also removed to show the incubation chamber. Illustrations by R. A. Dias. 


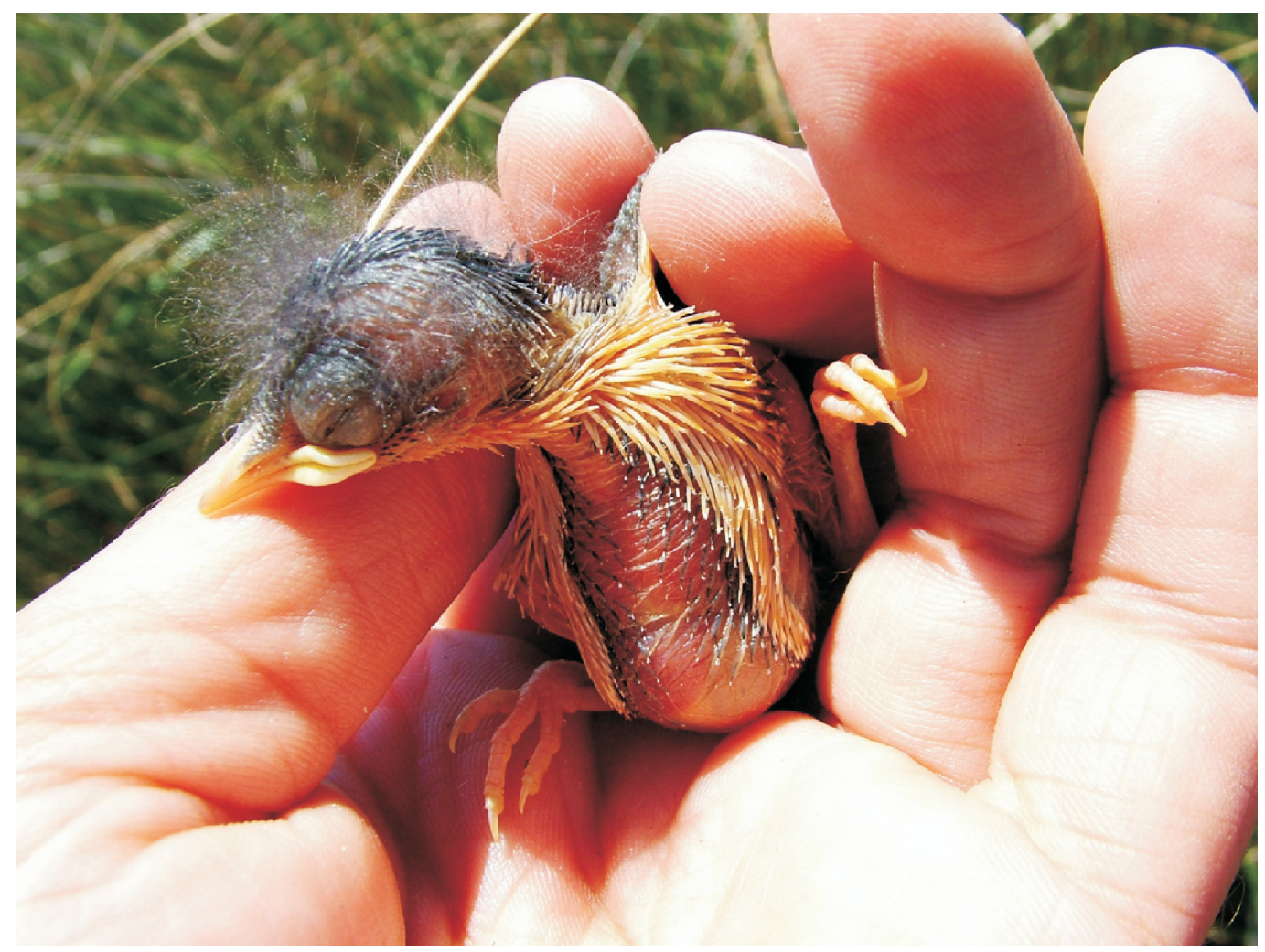

Fig. 4. Spartonoica maluroides (d'Orbigny \& Lafresnaye, 1837) nestling approximately five to six days old.

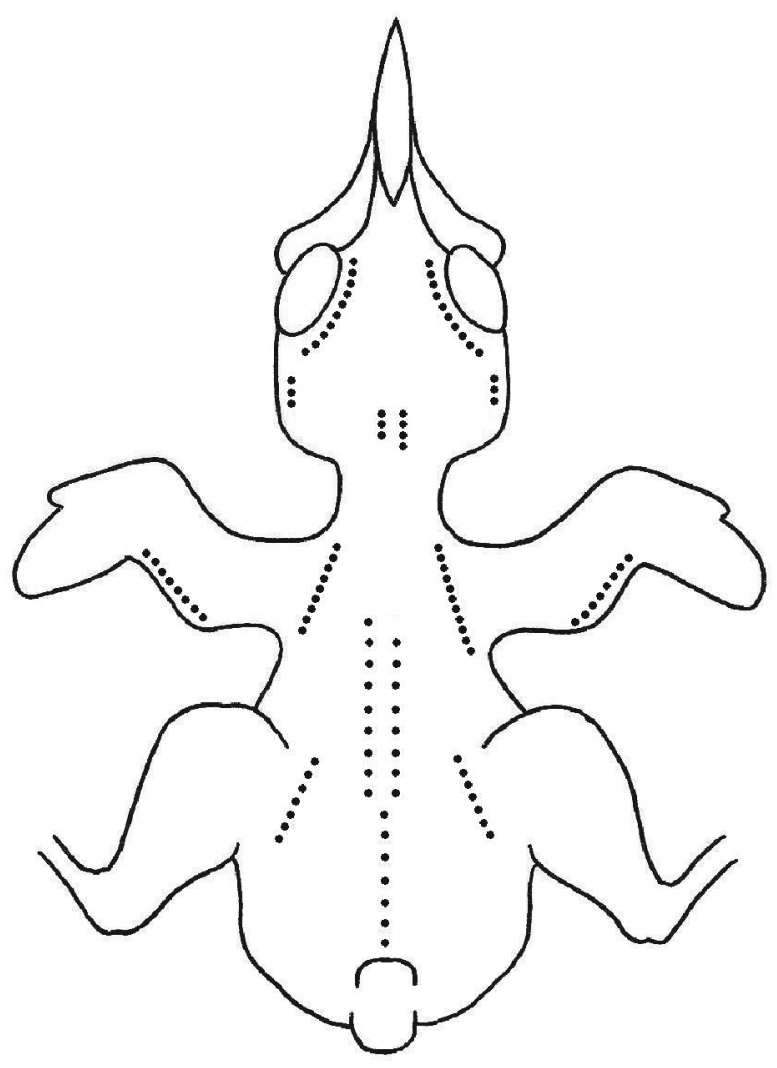

Fig. 5. Natal pterylosis of Spartonoica maluroides (d'Orbigny \& Lafresnaye, 1837). Each dot represents a single neossoptile. Illustration by R. A. Dias.
Table I. Measurements (in millimeters) and counts of neossoptiles of Spartonoica maluroides (d'Orbigny \& Lafresnaye, 1837).

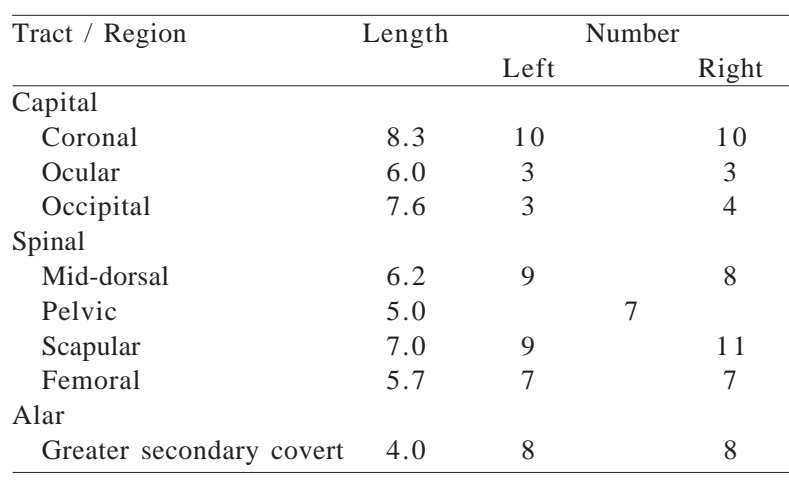

(\# 123C) to Yellow Ocher (\# 123C). The longest pin feathers measured $2.7 \mathrm{~mm}$ on the capital, $6.2 \mathrm{~mm}$ on the scapulohumeral, $6.0 \mathrm{~mm}$ on the dorsal, $5.0 \mathrm{~mm}$ on the femoral, $2.1 \mathrm{~mm}$ on the crural, $4.4 \mathrm{~mm}$ on the ventral and $5.6 \mathrm{~mm}$ on the caudal tracts. The longest pin feathers of the primaries and secondaries measured 10.0 and $8.5 \mathrm{~mm}$, respectively.

The bill, gape and mouth lining were Warm Buff (\# 18), whereas the flanges were Chamois (\# 123D). Skin color varied from Vinaceous (\# 3) to Flesh Color (\# 5). Legs and claws were Warm Buff (\# 18). The nestling measured $62 \mathrm{~mm}$. Bill length was $6.6 \mathrm{~mm}$, the skull measured $21.4 \mathrm{~mm}$ and the tarsus $12.8 \mathrm{~mm}$.

Parental behavior. We inferred that two adult birds attended the nest. On three occasions we observed two individuals simultaneously arriving on the tussock carrying food items in their bills and not showing any 
signs of aggression towards each other. On three other occasions, however, one of the nest attendants chased another adult individual - probably an intruder - from the surroundings of the nest. Moreover, when we approached the nest, only two adult birds reacted to our presence. No distraction movements were observed when we approached the nest. Adults flew away and took cover in the S. californicus patch, monitoring our activities from there. When we handled the nestlings, adults approached a little closer and called nervously. After we left the nest's vicinity, the birds returned and resumed their activities. Some Phleocryptes melanops (Viellot, 1817) (Aves, Furnariidae) and a lone Pseudocolopteryx sclateri (Aves, Tyrannidae) were often seen in the $S$. californicus patch, but the spinetails paid no attention to them.

We recorded at least 74 visits to the nest during the $c a .6 \mathrm{~h}$ study period. The average number of visits per hour was $12.8 \pm 1.3$. Differences in the number of visits recorded per hour were not significant $\left(\chi^{2}=0.53 ; p\right.$ $=0.97 ; n=5$ ). Birds apparently foraged within $100 \mathrm{~m}$ of the tussock, searching for food in the S. californicus patch and the S. olneyi stand (respectively 59 and $41 \%$ of the observations; $n=24$ ). Observed food items consisted entirely of small arthropods. Most measured less than $5 \mathrm{~mm}$ and could not be safely identified. A dragonfly (Odonata), a large fly (Diptera), a grasshopper (Orthoptera), three small butterflies (Lepidoptera) and two unidentified insect larvae were brought to the nestlings. Upon arrival, birds flew into the tussock from the nearby vegetation, generally landing on the upper lateral part of the plant before disappearing in its interior. No long direct flights were recorded. On some occasions, however, adults flew into the nearby vegetation and then to the ground, probably hopping along the base of the neighboring plants to reach the nest before entering it through lateral openings in the tussock. On seven occasions an adult left the nest carrying a fecal sac in its bill and dropped it a short distance away. When leaving with fecal sacs, adults spent $0.6 \pm 0.29$ minutes in the nest.

An adult bird spent on average $0.7 \pm 0.56$ minutes (min. $=0.13 ;$ max. $=2.67 ; n=49)$ inside the tussock attending nestlings. The nest remained unattended for $3.61 \pm 3.13$ minutes $(\min .=0.08 ; \max .=15 ; n=52)$. Throughout the study period, adults were away from the nest for at least $63 \%$ (or 224 minutes) of the total observation period. The hour of the day had no influence on the amount of time spent by an adult in the nest $\left(F_{1,47}=0.1 ; R^{2}{ }_{\text {adjusted }}=-1.9 \% ; p=0.7\right)$ or away from it $\left(F_{1,50}=0.3 ; R_{\text {adjusted }}^{2}=-1.4 \% ; p=0.6\right)$.

\section{DISCUSSION}

There is no consensus on the form of the nest of $S$. maluroides in the literature. Spherical nests mentioned by Hartert \& Venturi (1909) and VauRie (1980) are probably misidentified and refer to Cranioleuca sulphurifera (Burmeister, 1869) (Aves, Furnariidae) (NARosky et al., 1983). DuRnFord (1878), Pereyra (1938) and Hudson (1984) stated that the nest was open, whereas ZYsKowsKI \& PRUM (1999) considered it homologous with domed vegetative nests. NAROSKY (1973), who described three nests from Argentina, does not solve this matter, merely stating at the end of the final description: "This was the most closed of the nests studied...." VauRIE (1980), based on Narosky's descriptions, regarded them as open structures. As noted by NAROSKY (1973), most of this discussion is probably related to subjective interpretations by each author than to real biological differences among nests. Due to the "shapeless" nature of some nests (NAROSKY, 1973; VAURIE, 1980), the process of description is a difficult task. Add the lack of hierarchy of criteria and of standard nomenclature for nest descriptions (see Simon \& Pacheco, 2005), and the confusion is made.

All reliable nest descriptions (DuRNFORD, 1878; Pereyra, 1938; Narosky, 1973; Hudson, 1984; this study) indicate that the bird invariably builds a basal cup-like structure by weaving pieces of dead leaves and other kinds of vegetable matter with the leaves of the supporting plant. This cup is also invariably built at the base of an open space inside a tussock or clump of tall, dense, emergent vegetation. If the cavity is natural or made by the bird remains unsolved. In the Brazilian nest, the bird deliberately arranged live leaves of the supporting plant's core, loosely weaving and bending them to form the upper section of the lateral walls and a canopy with a distinct entering hole. This suggests that the shape of the cavity can, at least, be partially altered by its occupants. The deepness of the basal cup is apparently determined by the extent that the animal weaves upwards and, possibly, by the original shape of the cavity. NAROSKY (1973) often treated this cup as a pad, suggesting that it can be rather shallow.

According to the classification scheme proposed by SIMON \& PACHECO (2005), the Brazilian nest is a "cavity/ without tunnel/high cup". We consider it a cavity-nest because the part of the structure where the bird lays its eggs is located at the bottom of a hollowed-out space inside a plant. This cavity bears a distinct opening and is not visible from the outside. Furthermore, the dome of the nest is not built with material brought by the bird. Instead, it is comprised by the ceiling of the cavity, manipulated to some extent by the animal to form a protective cover. There is no access tunnel, as the cavity opens directly to spaces amidst the leaves of the supporting plant. A distinct, deep cup deliberately made by the bird stands at the bottom of the cavity and constitutes the section of the nest where the eggs are laid and incubated. The main difference to other cavitynesting ovenbirds is that the cavity is located inside tussocks or clumps of dense herbaceous vegetation and not in crevices among rocks or excavations in the ground or tree trunks. The nest is not closed (sensu SimON \& PAcheco, 2005) because its walls do not shelter completely the incubatory chamber. Instead, the walls of the cavity encircle the nest.

The Brazilian nest appears to be more regular in shape than the ones described by NAROSKY (1973). This may be a consequence of the overall structure of the plant in which the nest is built. Because $S$. densiflora tussocks are denser than $S$. californicus clumps, the Brazilian nest's inner chamber and especially its walls are more recognizable. This suggests that the shape of the 
nest may vary according to the species of supporting plant used, a feature that has been recently recorded in Argentina (Juan Pablo Isacch, pers. comm.).

Based on three nests described in NAROSKY (1973) and VAURIE (1980), and the Brazilian nest depicted above, we tentatively conclude that the incubation chamber measures ca.60-80 $\mathrm{mm}$ in diameter, and that the cavity in which the cup is built can measure ca. 60, 100 and $120 \mathrm{~mm}$ from the entrance hole to the deepest part of the incubation chamber. The width of the entrance hole can measure 30, 40, 45 and $80 \mathrm{~mm}$ and nests can be built from ground level to a height of $280 \mathrm{~mm}$. Direct comparisons between other available measurements are precluded by the lack of adequate terminology in previous descriptions. Spartonoica maluroides lines the floor of the brood chamber with soft material different in nature from that present in the nest's base and walls, notably fine straws, plant fibers, small feathers and sheep's wool (DURNFORD, 1878; Pereyra, 1938; NARosky, 1973; Hudson, 1984; this study). This feature is shared with some other furnariids, mostly species that build stick-nests (see ZYSKOWSKI \& PRUM, 1999).

Information from Argentina (GRANT, 1911; NAROSKY, 1973 ) and our Brazilian data suggest that $S$. maluroides prefers to nest at the edge or in shallow parts of wetlands, where water level is lower and receding waters during late spring and early summer allow this ground nesting bird to start nest construction. Since the species nests in cavities in tussocks of tall wetland plants, breeding may also be limited by the availability of adequate nesting sites. This may be determinant in wetlands similar to our study area, where the most abundant plant species are short and do not grow in tussocks. Wetland burning and overgrazing, widespread practices in saltmarshes of Rio Grande do Sul, may contribute to reduce even more nesting opportunities for this conservation-concern species.

The pterylosis of the capital and spinal tracts of $S$. maluroides is consistent with descriptions of other furnariids (Collins et al., 1991; Collins \& ARAYA, 2002). The distribution of neossoptiles in the ocular region forms a distinct pattern, a feature that can be typical of ovenbirds and their allies (Collins et al., 1991; Collins \& ARAYA, 2002). In five other species of furnariids the total number of neossoptiles ranges from 121 to 354 (COLlins \& ARAYA, 2002). Therefore, the total number of neossoptiles in this specimen is the lowest recorded for the family. Main differences to other species refer to the absence or numeric reduction of downs in the ventral, caudal and alar regions. As abrasion does not completely remove neossoptiles from whole tracts and regions (Charles T. Collins, pers. comm.), the low count recorded for this specimen may be biologically determined. Intraspecific variation has been detected in natal pterylosis analysis based on large sample sizes (CLARK, 1967; Collins, 1990). Consequently, collations above are hampered by the inadequate number of specimens in this and other studies of ovenbird neossoptiles (Collins et al., 1991; Collins \& Araya, 2002).

The size of the breeding territory could not be determined because no other $S$. maluroides nested in the vicinity. Contrary to most furnariids (Remsen, 2003), this spinetail does not defend year-round territories, as noted during autumn and winter visits made by the authors to the study area. Our experience with the species also indicates that lone birds (males?) sing from somewhat prominent perches during spring (BENCKE et al., 2003), indicating that breeding territories are established and defended on a yearly-basis. Our observations also confirm that male and female care for the nestlings, as other ovenbirds do (REMSEN, 2003). Food items delivered to chicks are in accordance with what is known of the species' diet (REMSEN, 2003). Winged insects are probably gleaned from the foliage, since we never saw this bird chasing insects in flight. The lack of correlation between the duration of feeding bouts and the time of the day can be explained by the fact that invertebrate prey items are expected to be active throughout the afternoon, when the temperature is highest. Nevertheless, the emergence of other patterns may have been hampered by our very limited sampling period. Feeding rates fall inside the range established for other Furnariidae (FRAGA, 1980; NoRES \& Nores, 1994; Auer et al., 2007; Moreno et al., 2007). However, adequate comparisons are once more precluded by our low sample size and the lack of standardized methods among studies. Clutch size in this species is 3 4 eggs (Hartert \& Venturi, 1909; Grant, 1911; Pereyra, 1938; NAROSKY et al., 1983). Therefore, hatching success would have been $75-100 \%$.

The uniqueness of the species breeding behavior among ovenbirds constitutes an opportunity to test hypothesis on avian life-history evolution. Because the species breeds in a relatively accessible nest on the ground, it may face nest predation from small mammals and snakes. Life history theory and Skutch's hypothesis (see MARTIN et al., 2000; MARTIN, 2004) predict that this species should face higher nest predation than birds that nest in more protected situations and therefore have lower food delivery-rates and bigger food items, as well as comparably shorter nestling period and lower clutch size. Furthermore, begging calls of $S$. maluroides are expected to have higher frequency and lower amplitude than species facing lower rates of nest predation, minimizing locatability by predators (BRISKIE et al., 1999). Our brief observations hinder adequate conclusions, but further studies on the species' breeding biology should focus on these aspects. Other facets of its breeding biology that should be evaluated include pair-bond, nest-site fidelity and the influence of human activities on its reproductive success. Virtually nothing is known on the species nesting preferences and limitations. We also recommend that future nest descriptions should follow proper criteria and standard nomenclature to ensure comparability. Knowledge on natal pterylosis of this and other ovenbirds should be improved, not only to infer phylogenetic relationships but also to test if closed-nest species tend to have fewer neossoptiles than open-cup nesters, as suggested by Collins \& McDANIEL (1989).

Our observations allied with previous information (BENCKE et al., 2003) confirm that $S$. maluroides is a resident breeder in southern Brazil and that the saltmarshes of the Lagoa do Patos estuary are an important year-round habitat for the species. We recommend that saltmarshes along the fringes of Lagoa 
Pequena be included in the limits of the "Estuário da Laguna dos Patos" Important Bird Area (RS129) (BENCKE et al., 2006) and that adequate protection is granted to the breeding habitat of this Pampas endemic.

Acknowledgments. We thank Kristof Zyskowski, Charles T. Collins, and Juan Pablo Isacch for comments and insights that improved the manuscript. Charles T. Collins, Rosendo M. Fraga and Giovanni N. Maurício kindly provided literature. We are also indebted to Douglas L. Farias, who voluntarily assisted during fieldwork. The research program of Universidade Católica de Pelotas financed expeditions to the study area.

\section{REFERENCES}

Altman, S. A. 1974. Observational study of behavior: sampling methods. Behavior 49:227-265.

Asmus, M. L. 1998. A Planície Costeira e a Lagoa dos Patos. In: Seeliger, U.; Odebrecht, C. \& Castello, J. P. orgs. Os ecossistemas costeiro e marinho do extremo sul do Brasil. Rio Grande, Ecoscientia. p.9-12.

Auer, S. K.; Bassar, R. D.; Fontaine, J. J. \& Martin, T. E. 2007. Breeding biology of passerines in a subtropical montane forest in northwestern Argentina. The Condor 109:321-333.

Ayres, M.; Ayres Jr., M.; Ayres, D. L. \& SAntos, S. A. 2007. BioEstat 5.0: Aplicações estatísticas nas áreas das ciências biológicas e médicas. Belém, Sociedade Civil Mamirauá. 364p.

Belton, W. 1984. Birds of Rio Grande do Sul, Brazil. Part 1: Rheidae through Furnariidae. Bulletin of the American Museum of Natural History 178:369-636.

1994. Aves do Rio Grande do Sul, distribuição e biologia. São Leopoldo, Ed. Unisinos. 584p.

Bencke, G. A.; Fontana, C. S.; Dias, R. A.; Maurício, G. N. \& Mähler JR., J. K. F. 2003. Aves. In: Fontana, C. S.; Bencke, G. A. \& ReIs, R. E. orgs. Livro vermelho da fauna ameaçada de extinção no Rio Grande do Sul. Porto Alegre, EDIPUCRS. p.189-479.

Bencke, G. A.; Maurício, G. N.; Develey, P. F. \& Goerck, J. M. orgs. 2006. Áreas importantes para a conservação das aves no Brasil: Parte I - Estados do Domínio da Mata Atlântica. São Paulo, SAVE Brasil. 494p.

BirdLife International. 2007. Species factsheet: Spartonoica maluroides. Available at: 〈http://www.birdlife.org>. Acessed on: 07.05.2008.

Bosque, C. \& Lentino, M. 1987. The nest, eggs, and young of the White-whiskered Spinetail (Synallaxis [Poecilurus] candei). Wilson Bulletin 99:104-106.

Briskie, J. V.; Martin, P. R. \& Martin, T. E. 1999. Nest predation and the evolution of nestling begging calls. Proceedings of the Royal Society of London 266:2153-2159.

CLARK, G. A. 1967. Individual variation in natal pterylosis of Red-winged Blackbirds. Condor 69:423,424.

Clench, M. H. 1970. Variability in body pterylosis, with special reference to the genus Passer. Auk 87:650-691.

Collins, C. T. 1990. Interspecific variation in the natal pterylosis of the Ochre-bellied Flycatcher Mionectes oleagineus (Tyrannidae). Bulletin of the British Ornithologists Club 110:143-145.

Collins, C. T. \& Araya, T. A. 2002. Natal pterylosis of two Trinidadian ovenbirds (Furnariidae). Department of Life Sciences, University of the West Indies, St. Augustine, Occasional Paper 11:18-22.

Collins, C. T.; Marín, A. M. \& Lentino, R. M. 1991. Natal pterylosis of Premnoplex brunnescens, Thripadectes virgaticeps and Synallaxis candei (Furnariidae). Bulletin of the British Ornithologists Club 111:118-120.
Collins, C. T. \& McDaniel, K. M. 1989. The natal pterylosis of closed-nest building tyrant flycatchers (Aves: Tyrannidae). Bulletin of the Southern California Academy of Sciences 88:122-130.

Dias, R. A. \& Burger, M. I. 2005. A assembléia de aves de áreas úmidas em dois sistemas de cultivo de arroz irrigado no extremo sul do Brasil. Ararajuba 13:63-80.

Durnford, H. 1878. Notes on the birds of the Province of Buenos Ayres. Ibis 2:58-68.

FraGA, R. M. 1980. The breeding of Rufous Horneros (Furnarius rufus). Condor 82:58-68.

Fraga, R. M. \& Narosky, S. 1985. Nidificación de las aves argentinas (Formicariidae a Cinclidae). Buenos Aires, Asociación Ornitológica del Plata. 100p.

Grant, C. H. B. 1911. List of birds collected in Argentina, Paraguay, Bolivia and southern Brazil, with field notes. Ibis 5:80-137

Hartert, E. \& Venturi, S. 1909. Notes sur les oiseaux de la République Argentine. Novitates Zoologicae 16:159-267.

Hudson, G. E. 1984. Aves del Plata. Buenos Aires, Libros de Hispanoamérica. 361p. Trad. e red. em 1984.

Martin, T. E. 2004. Avian life-history evolution has an eminent past: does it have a bright future? The Auk 121:289-301.

Martin, T. E.; Martin, P. R.; Olson, C. R.; Heidinger, B. J. \& Fontaine, J. J. 2000. Parental care and clutch sizes in North and South American birds. Science 287:1482-1485.

Moreno, J.; Merino, S.; Lobato, E.; Rodríguez-Gironés, M. A. \& VÁsquez, R. A. 2007. Sexual dimorphism and parental roles in the Thorn-tailed Rayadito (Furnariidae). The Condor 109:312-320.

NARosky, S. 1973. Observations on the nesting of Spartonoica maluroides. Ibis 115:412,413.

Narosky, S.; Fraga, R. \& DE LA PeÑa, M. 1983. Nidificación de las aves argentinas (Dendrocolaptidae y Furnariidae). Buenos Aires, Asociación Ornitológica del Plata. 98p.

Nores, A. I. \& Nores, M. 1994. Nest building and nesting behavior of the Brown Cacholote. Wilson Bulletin 106:106-120.

Pereyra, J. A. 1938. Aves de la zona ribereña nordeste de la Provincia de Buenos Aires. Memorias del Jardín Zoológico de La Plata 9:1-304.

Remsen, J. V. 2003. Family Furnariidae (Ovenbirds). In: DEL Hoyo, J.; Elliott, A. \& Christie, D. eds. Handbook of the birds of the world. Barcelona, Lynx Edicions. v.8, p.189-479.

Ridgely, R. S. \& Tudor, G. 1994. The birds of South America. Vol. 2 - The suboscine passerines. Austin, University of Texas. v.2, $814 \mathrm{p}$

Rosa, M. 1985. Geografia de Pelotas. Pelotas, Editora da Universidade Federal de Pelotas. 333p.

SICK, H. 1997. Ornitologia Brasileira. Rio de Janeiro, Nova Fronteira. 912p.

Smithe, F. B. 1975. Naturalist's Color Guide. New York, American Museum of Natural History. 228p.

Simon, J. E. \& PACHeCO, S. 2005. On the standardization of nest descriptions of neotropical birds. Revista Brasileira de Ornitologia 13:143-154

VAURIE, C. 1980. Taxonomy and geographical distribution of the Furnariidae (Aves, Passeriformes). Bulletin of the American Museum of Natural History 166:1-357.

Wetherbee, K. D. 1957. Natal plumages and downy pteryloses of passerine birds of North America. Bulletin of the American Museum of Natural History 113:339-436.

Wetmore, A. 1926. Observations on the birds of Argentina, Paraguay, Uruguay and Chile. United States Natural Museum Bulletin 133:1-448.

Zyskowski, K. \& Prum, R. O. 1999. Phylogenetic analysis of the nest architecture of the Neotropical ovenbirds (Furnariidae). Auk 116:891-911. 